Cornell University Law School Scholarship@Cornell Law: A Digital Repository

\title{
Drafting Chapter 2 of the ALI's Employment Law Restatement in the Shadow of Contract Law: An Assessment of the Challenges and Results
}

Robert A. Hillman

Cornell Law School, rah16@cornell.edu

Follow this and additional works at: http://scholarship.law.cornell.edu/clsops_papers

Part of the Contracts Commons, and the Labor and Employment Law Commons

\section{Recommended Citation}

Hillman, Robert A., "Drafting Chapter 2 of the ALI's Employment Law Restatement in the Shadow of Contract Law: An Assessment of the Challenges and Results" (2014). Cornell Law Faculty Working Papers. Paper 118.

http://scholarship.law.cornell.edu/clsops_papers/118 


\title{
Drafting Chapter 2 of the ALI's Employment Law Restatement in the Shadow of Contract Law: An Assessment of the Challenges and Results
}

\author{
Robert A. Hillman
}

The American Law Institute (ALI) has just completed the Restatement of the Law Third, Employment Law. ${ }^{1}$ Chapter 2 is entitled "Employment Contracts: Termination." As the name suggests, the Chapter focuses on the law's difficult challenge of applying contract law to distinguish lawful terminations of employees from wrongful ones. The question is especially problematic because, on the one hand, employment law's long-existing default rule allows employers to terminate employees "at will" and without cause. Advocates of the at-will doctrine present several policies to support it, including freedom of contract and efficiency. ${ }^{2}$ On the other hand, employers seek to attract talented employees and, once employed, establish an "orderly, cooperative and loyal work force."3 Toward that end, numerous judicial decisions and scholarly research reveal unsurprisingly that employers design their communications to attract employees and create loyal workers. ${ }^{4}$ Further, as I have stated elsewhere, some communications

induce employees to change jobs, forgo job searches, accept job conditions, or otherwise change position. In the context of a plentiful labor supply, high costs of employee relocation, and material and psychic investments by employees in their jobs, non-union employees often lack the bargaining power, resources, information, and wherewithal to withstand employer inducements. ${ }^{5}$

It is no wonder, then, that contract law's approach to indefinite-duration employment issues includes decisions policing employer overreaching and thereby creating rules that limit employment at will. ${ }^{6}$

Given this clash of policies, the primary challenge for the reporters of the new employment restatement in Chapter 2 was to search the cases and identify the circumstances in which terminated employees should be entitled to legal protection, no easy task given the multitudinous and amorphous case law on employment discharge, the dynamic labor market atmosphere and, perhaps most important, contract law's lack of a unifying theory of its own.

\footnotetext{
${ }^{1}$ The Restatement is denominated "Third," which is bound to cause some confusion because its preamble proclaims that it is the first ever Restatement of employment law.

${ }^{2}$ See infra notes , and accompanying text. See also Robert A. Hillman, The Unfulfilled Promise of Promissory Estoppel in the Employment Setting, 31 Rutgers L. Rev. 1, 25-26 (1999) (hereinafter "Unfulfilled Promise") (discussing arguments in favor and opposed).

${ }^{3}$ Touissaint v. Blue Cross \& Blue Shield, 292 N.W.2d 880, 892 (Mich. 1980).

${ }^{4}$ Hillman, "Unfulfilled Promise," supra note , at 4.

${ }^{5}$ Id. at 4-5 (footnotes omitted).

${ }^{6}$ I refer to principles favorable to employees in indefinite duration contracts as counter-rules not exceptions to reflect the ambivalence on whether at-will or the counter-principles form the central core of employment contract termination.

${ }^{7}$ Stewart Schwab sees some coherence in termination law:
} 
Related to this challenge, the ALI's conception of a restatement seemingly allows reporters to venture beyond describing the law (but cautiously). ${ }^{8}$ The reporters therefore had to decide what constitutes the appropriate mix of description and prescription in their efforts to assess the contradiction in employment policies.

This essay focuses on Chapter 2's treatment of employment at will, on the one hand, and promissory estoppel and good faith, on the other, as examples of how Chapter 2 meets these challenges. The essay concludes that Chapter 2 establishes a useful framework and helpfully identifies the issues for the courts. Because promissory estoppel and good faith (and other contract doctrines) are themselves indistinct, however, Chapter 2 often cannot resolve the principle and counter-principle dilemma in particular cases and therefore cannot fully satisfy ALI's goal of clarifying and modernizing the law through restatements. For the same reason, I doubt that a project in the form of a restatement will be particularly helpful in enhancing employee protection if the playing field is uneven.

Part I of this paper focuses on Chapter 2's treatment of employment at will, promissory estoppel, and good faith. Part II evaluates the approaches and argues that the Chapter establishes a helpful framework. Part II also asserts that the Chapter leaves much for case law development, which is inevitable when drafting in the shadow of contract law. Part III ruminates on what a Principles of Employment Law: Termination could have looked like, freed from the strictures of a restatement.

\section{An Overview of "Employment Contracts: Termination"}

Section 2.01 of Chapter 2 of the Restatement presents the at-will principle and inventories the counter-rules treated in subsequent sections of the Chapter. I focus on Sections 2.01 (at-will default rule), 2.02(b) (promissory estoppel), and 2.07 (implied duty of good faith and fair dealing). The issues I identify are not unique to these sections, but instead illustrate the challenges of restating employment termination law in the shadow of general contract law.

\section{A. Section 2.01: Default Rule of an At-Will Employment Relationship}

The life-cycle framework that courts have developed provides the parties in a career employment relationship a legal structure that checks opportunistic behavior. Its fundamental premise is that both employer and employees can act opportunistically. Consequently, a life-cycle analysis does not categorically condemn or celebrate employment at will. It supports, in broad outline, the contract law inroads that have been made on the at-will doctrine, particularly at the beginning and the end of an employee's career, and it explains the continued vitality of the at-will rule for midcareer employees. The current position of the courts is superior to a dogmatic insistence on the old at-will regime, which creates an excessive risk of opportunistic terminations for long-term, and sometimes beginning-career workers. Moreover, the current hesitant, intermediate position may also be superior to a general just-cause standard, which would lead to excessive shirking by midcareer workers.

Stewart Schwab, Life-Cycle Justice: Accommodating Just Cause and Employment At Will, 92 Mich. L. Rev. 8 (1993).

${ }^{8}$ See infra notes , and accompanying text. 
Section 2.01 affirms the employment-at-will principle, but also references the counterrules:

Either Party may terminate an employment relationship with or without cause unless the right to do so is limited by a statute, other law or public policy, or a 2.02 agreement, binding employer promise, or binding employer statement.

Comment $b$ conceptualizes the employment relationship as contractual, meaning that contract law's set of default rules apply unless displaced by the parties' agreement or other law. ${ }^{9}$ Comment $b$ and the Reporters' Notes point out that 49 states include some form of the employment-at-will default rule. Comments $c$ through $e$ reference the series of counter-rules listed in Section 2.01's boilerplate. Section 2.01 thus sets up the chasm between rule and counter-rule that the drafters address in the rest of the Chapter.

Advocates of both the at-will rule and the counter-rules pronounce strong policy reasons in support of their positions. ${ }^{10}$ In brief, theorists in favor of the at-will rule cite freedom of contract and assert that the rule reflects the parties understanding of their relationship. ${ }^{11}$ In addition, the rule arguably is efficient because "'in the face of uncertain changes in technology and business, [the rule] allows parties to exit precisely"' when the gains from doing so exceed the gains from continuing the employment. ${ }^{12}$ Further, based on their observation of relatively few for-cause employment contracts and their surmise that employees receive higher pay for at-will arrangements, proponents assert that the parties seek such agreements. ${ }^{13}$ In addition, the threat of termination without cause arguably creates incentives in employees not to shirk or otherwise misbehave. ${ }^{14}$ Finally, courts may apply employment at will most often to mid-term employees, precisely when employee shirking is most prominent. ${ }^{15}$

On the other hand, supporters of the counter-rules refer to the adverse consequences of the at-will principle because of employees' financial dependence and lack of mobility. ${ }^{16}$ In addition, contrary to the proponents of at-will employment, supporters of the counter-rules claim that employees expect only for-cause termination and worry about inappropriate employer

\footnotetext{
${ }^{9}$ For a discussion of employment agreements as contracts, see infra notes , and accompanying text.

${ }^{10}$ Some of these arguments are found in Comment $a$ to Section 2.01.

${ }^{11}$ Reporters' Notes, Comment $a$; see also id. citing Richard Epstein, In Defense of the Contract at Will, 51 U. Chi. L. Rev. 947 (1984) and Andrew P. Morriss, Bad Data, Bad Economics and Bad Policy: Time to Fire Wrongful Discharge Law, 74 Tex. L. Rev. 1901 (1996) (employers have a property right in at-will employment)

${ }^{12}$ Hillman, Unfulfilled Promise, supra note, at 26, quoting Sherwin Roswen, Commentary: In Defense of the Contract at Will, 51 U. Chi. L. Rev. 983, 983 (1984).

${ }^{13}$ See, e.g., Epstein, supra note .

${ }^{14} \mathrm{Id}$.

${ }^{15}$ Schwab, supra note .

${ }^{16}$ See, e.g., Rachel Arnow-Richman, Just Notice: Re-Reforming Employment at Will, 58 UCLA L. Rev. 1, 9 (2010).
} 
motives for terminating them. ${ }^{17}$ Employees also may reasonably rely on employer communications that suggest for-cause employment, as the next subsection suggests. ${ }^{18}$

B. Section 2.02: Agreements and Binding Employer Promises or Statements Providing for Terms Other Than At-Will Employment

Section 2.02 provides in (a) that employment is not terminable at will if the parties have an agreement otherwise. Subsections (c) through (e) refer to employer policy statements, good faith, and "other established principles" as also limiting employment at will. Section 2.02(b), the focus here, states that "[t]he employment relationship is not terminable at will by an employer if $* * *$ a promise by the employer to limit termination of employment reasonably induces detrimental reliance by the employee (2.02, Comment $c)$."

Section 2.02(b) and its reference to Comment $c$ invoke the doctrine of promissory estoppel. Restatement (Second) of Contracts Section 90 supplies the promissory estoppel rule that courts almost uniformly apply. It reads:

A promise which the promisor should reasonably expect to induce action or forbearance on the part of the promisee or a third person which does induce such action or forbearance is binding if injustice ca be avoided only by enforcement of the promise. ${ }^{19}$

Initially promissory estoppel supplied a remedy for a promisee's reasonable but uncompensated reliance on a gift promise. ${ }^{20}$ Courts expanded the doctrine to enforce promises in contracts that were unenforceable for reasons such as indefiniteness or the lack of a writing, ${ }^{21}$ and courts now even apply it at the negotiating stage. ${ }^{22}$ Despite this expansion and although analysts surmised that promissory estoppel would dominate in the courts, it has not been very successful overall. ${ }^{23}$ Part of the reason is that enforcing promises outside of the traditional theory of bargained-for exchange is controversial. ${ }^{24}$ It is therefore not surprising that employees face formidable hurdles when bringing promissory estoppel claims. The following discussion considers and adds to the employment Restatement's treatment of promissory estoppel and inventories the significant hurdles employees face in bringing such a claim.

1. Was there a promise?

\footnotetext{
${ }^{17}$ Id. at 10.

${ }^{18}$ Reporters' Notes, Comment $a$. But a just-cause rule may not sufficiently protect employees who may be unable to prove employer arbitrariness. See Arnow-Richman, supra note , at 17-21; infra notes , and accompanying text.

${ }^{19}$ Restatement (Second) of Contracts 90 (1979).

${ }^{20}$ Restatement (Second) of Contracts 71 (1979).

${ }^{21}$ Hillman, Unfulfilled Promise, supra note , at 3-4, citing Daniel A. Farber \& John H. Matheson, Beyond Promissory Estoppel: Contract Law and the "Invisible Handshake, 52 U. Chi. L. Rev. 903, 907 (1985).

${ }^{22}$ See, e.g., Hoffman v. Red Owl Stores, 133 N.W. 2d 267 (Wis. 1965).

${ }^{23}$ Robert A. Hillman, Questioning the 'New Consensus' on Promissory Estoppel: An Empirical and Theoretical Study, 98 Colum. L. Rev. 580 (1998).

${ }^{24}$ See, e.g., William C. Whitford and Stewart Macaulay, Hoffman v. Red Owl Stores, The Rest of the Story, 61 Hastings L. J. 801 (2010).
} 
A promise consists of "an assurance, in whatever form of expression given, that a thing will or will not be done. *** [A promise is] meant to give an assurance as to a future event."25 Courts must distinguish general statements such as compliments about work quality or positive statements about an employee's career from definite assurances of job security. ${ }^{26}$ Comment $c$ to Section 2.02 specifically refers to this challenge: "The promise $* * *$ must be sufficiently definite to reasonably induce the action taken in reliance on the promise." Nevertheless, some courts find that an implied promise is enough. For example, one court found that an employer's listing of sanctions if an employee interviewed elsewhere meant that the employer "promised" not to increase the sanctions beyond those listed. ${ }^{27}$ Another employer told its employee that "she did not need to look for another job" and the court found that statement actionable. ${ }^{28}$

The majority of courts, however, seem too willing to grant summary judgment against the employee on the question of whether the employer made a definite promise. Statements such as "your job is secure," "there is no need *** to look elsewhere," 29 "[you] will continue to have a career with [the employer] until age sixty-five," ${ }^{30}$ and [you will] remain employed by the company"31 $^{31}$ should be sufficient for an employee to defeat summary judgment on the issue of whether the employer made a definite promise, but the courts considering these statements did not agree. ${ }^{32}$

In addition, some courts too easily find on a motion for summary judgment that any promise made was too ambiguous to enforce. These courts look for unnecessary detail that the law should require only for enforcing a contract, such as a specific duration or compensation. ${ }^{33}$ Comment $c$ to Section 2.02 appears to dismiss the need for such specificity at least in the case of an oral agreement: "Where the conditions for promissory estoppel are present, promises may be enforceable even though an agreement itself would not be enforceable for lack of a written document."

2. Did the employee rely on the promise?

A prominent issue is whether the employer made the promise concerning job terms or retirement benefits before or after the employee agreed to the employment or decided to retire. ${ }^{34}$ If the agreement or retirement came first, of course, the employee cannot show that the promise induced the reliance, a requirement made explicit in Comment $c$ to section 2.02. In addition, I have previously written that

\footnotetext{
${ }^{25}$ Baehr v. Penn-O-Tex Oil Corp., 104 N.W.2d 661, 665 (Minn. 1960).

${ }^{26}$ Hillman, Unfulfilled Promise, supra note at 12.

${ }^{27}$ Board v. Simmons Industries, Inc., 1994 WL 454738 (Minn. Ct. App. 1994).

${ }^{28}$ Howard v. Kuehnert, 1996 WL 145517 (Ohio Ct. App. 1996).

${ }^{29}$ Corradi v. Soclof, 1995 WL 322311 (Ct. App. Ohio), discussed in Hillman, Unfulfilled Promise, supra note , at 13.

${ }^{30}$ Dickens v. Equifax Services, Inc., 1996 WL 192973 (10th Cir. 1996), discussed in Hillman, Unfulfilled Promise, supra note , at 14.

${ }^{31}$ Id. The court stated that the supervisor's statements "were not sufficiently definite to be legally enforceable promises for purposes of establishing promissory estoppel." Id. at *6.

${ }^{32}$ Hillman, Unfulfilled Promise, supra note , at 12-15.

${ }^{33}$ Hillman, Unfulfilled Promise, supra note at 15; see, e.g., Schoeneck v. Chicago Nat'l League Ball Club, Inc., 867 F. Supp. 696, 703 (N.D. Ill. 1994).

${ }^{34}$ Hillman, Unfulfilled Promise, supra note at 15
} 
[a]s a general matter, courts required employees to allege and establish more than that they accepted or continued a job or failed to look for a substitute job. Employees had to show that they rejected other distinct offers or opportunities. Courts ignored the fact that failing to enter the job market itself could constitute a distinct detriment that would severely undermine an employee's ultimate prospect for career success. ${ }^{35}$

Illustrations 1 and 2 to Comment $c$ follow the decisions that require employees to demonstrate that they turned down a distinct offer.

\section{Was the reliance reasonable?}

Although the Restatement (Second) of Contracts Section 90 focuses on whether "the promisor should reasonably expect [the promise] to induce action or forbearance," most courts focus on the promisee and ask whether the promisee's reliance was reasonable. ${ }^{36}$ This is not a serious divergence from Section 90 because a promisor should reasonably have expected the promisee to rely when the promisee's reliance was reasonable. At any rate, demonstrating the reasonableness of the employee's reliance may be the employee's most difficult hurdle. Courts justifiably are troubled by the reasonableness of reliance if the parties have not yet nailed down a contract or an existing contract contradicts promises or representation made less formally. ${ }^{37}$

Courts have found that employees who receive inconsistent messages about their employment cannot reasonably rely on the favorable one. ${ }^{38}$ This, of course, disfavors employees if an employer makes promises to induce the employee to agree to employment only to disclaim the promised benefits in a subsequent written contract. ${ }^{39}$ Courts have also held against employees in the opposite situation where the employee signs a written at-will agreement or even just receives notice of such, but then relies on a later contradictory communication promising job security. ${ }^{40}$ In addition, courts find reliance unreasonable if the employer's communication was vague or ambiguous. ${ }^{41}$

4. Was the reliance unforeseeable?

If an alleged employer's promise was indistinct or uncertain, it is an easy step for courts to find any employee reliance unforeseeable. For example, in one case, an employee relied on the employer's failure to give the employee a scheduled job appraisal as indicating that his job was

\footnotetext{
${ }^{35}$ Id. at 16.

${ }^{36}$ Robert A. Hillman, Principles of Contract Law 97 (2014).

${ }^{37}$ See generally Whitford and Macaulay, supra note .

${ }^{38}$ See, e.g., Coll v. PB Diagnostic, Inc., 50 F.3d 1115, 1124 (1st Cir. 1995), discussed in Hillman, Unfulfilled Promise, supra note , at 16-17.

${ }^{39}$ See, e.g., Coll v. PB Diagnostic, Inc., 50 F.3d 1115, 1124 (1st Cir. 1995).

${ }^{40}$ Hillman, Unfulfilled Promise, supra note at 17.

${ }^{41}$ See, e.g., Coll v. PB Diagnostic, Inc., 50 F.3d 1115, 1124 (1st Cir. 1995), discussed in Hillman, Unfulfilled Promise, supra note , at 17.
} 
secure. The court found that the employer "had no reason to expect" the employee to rely on this omission. $^{42}$

\section{Other reasons}

Employees face additional hurdles to proving promissory estoppel. I have summed these up elsewhere:

Courts dismissed employee promissory estoppel claims for an assortment of additional reasons. These included the speculative nature of the damages, the lack of injustice because the employee did not have sufficient education for the position promised, the statute of frauds, and the preemption by ERISA. In addition, claimants faced long odds when the employer was a public agency: "[C]ourts have consistently refused to give effect to government fostered expectations that, had they arisen in the private sector, might well have formed the basis for a contract or an estoppel."43

This brief assessment of promissory estoppel in the employment context shows that the employment Restatement's recognition of the theory does not do very much to clarify the doctrine in the employment termination context. In addition, employees will continue to have an uphill battle attempting to prevail on the theory. But, in the tradition of an ALI Restatement, Section 2.02(b) contributes by affirming promissory estoppel's availability in the at-will termination setting despite some jurisdictions that do not recognize or narrow its use. ${ }^{44}$

\section{Section 2.07 Implied Duty of Good Faith and Fair Dealing}

Under Section 205 of the Restatement (Second) of Contracts, every contract includes an obligation of good faith. According to Section 2.07 of the employment Restatement, employment contracts are no exception, notwithstanding the Section's recognition of the conflict among jurisdictions on whether a good faith obligation exists in employment-at-will circumstances. ${ }^{45}$ Undaunted, Section 2.07 provides that each party to an employment contract owes the other "a non-waivable duty of good faith and fair dealing." 46

What is the nature of the good faith obligation adopted by the employment Restatement? Although the obligation of good faith has many roles in contract law, including good faith purchase and good faith modification, good faith performance is the subject of Section 2.07. Good faith performance has a long history and writers have spilled lots of ink explaining it. ${ }^{47}$ Briefly, good faith performance "excludes a variety of types of conduct characterized as involving 'bad faith' because they violate community standards of decency, fairness or

\footnotetext{
${ }^{42}$ See Dunn v. NPM Healthcae Prods; Inc., 1994 WL 468281 (Conn. Super. Ct. 1994), discussed in Hillman, Unfulfilled Promise, supra note at 18.

${ }^{43}$ Hillman, Unfulfilled Promise, supra note at 19.

${ }^{44}$ See Section 2.02, Reporter's Notes Comment $c$.

${ }^{45}$ Section 2.07, Reporters' Notes, Comment $a$.

${ }^{46}$ Section 2.07(a).

${ }^{47}$ For one treatment of its history, see Mathew W. Finkin et al., Working Group on Chapter 2 of the Proposed Restatement of Employment Law: Employment Contracts: Termination, 13 Emp. Rts. \& Emp. Pol'y 93, 135 (2009).
} 
reasonableness." ${ }^{48}$ Courts identify such violations through the process of contract interpretation and gap filling. ${ }^{49} \mathrm{~A}$ court can interpret the content of a contract to include an implied good-faith obligation consistent with the parties' reasonable expectations. ${ }^{50}$ In so doing, the court may draw on its view of what "decency, fairness or reasonableness" requires, ${ }^{51}$ based on the theory that the parties must have intended to include such principles in their agreement: "Intention not otherwise revealed may be presumed to hold in contemplation the reasonable and probable." ${ }^{52}$ Alternatively a court can simply conclude that good faith is a mandatory term that imports the community's view of decency and fairness regardless of expectations. ${ }^{53}$ Typically, a party is in bad faith, however, only if its motive in performing the contract is to deprive the other party of what it reasonably expected or community standards require. ${ }^{54}$

Section 2.07(a) of the employment Restatement expressly identifies two kinds of "nonwaivable" bad faith. The section provides that the good-faith obligation "includes an agreement by each" party not to hinder the other party's performance or to deprive that party of the benefit of the contract. This language suggests that the employment Restatement's good-faith obligation is mandatory gap filler and does not require a reasonable expectations inquiry, although in actuality each path would most often lead to the same result. ${ }^{55}$ Section 2.07 (a) does not bar other instances of bad faith, although depriving the other party of the benefits of the contract goes a long way towards remedying much of the employer excesses identified in the cases.

Section 2.07(b) seeks to situate the good-faith obligation within the context of employment at will. Here things get dicey. Subsection (b) emphasizes that the at-will default rule applies notwithstanding "non-waivable" good faith: good faith "cannot be used to require cause for termination in an employment agreement otherwise terminable at will." Does this suggest that good faith is waivable after all if the parties agree to an at-will arrangement? The challenge for the drafters, of course, was to harmonize these seemingly contradictory principles. Perhaps this is not impossible, at least if examined through the lens of the reasonable expectations approach to good faith. As one court said, "[t]hese two concepts can coexist if careful attention is paid to the objectively reasonable expectations of the parties to a contract of employment atwill." ${ }^{56}$ But what are the parties' reasonable expectations in at-will cases? More specifically,

\footnotetext{
${ }^{48}$ Restatement (Second) of Contracts, 205, cmt. a.

49 "[T]he source of good faith lies on the border between contract interpretation and gap filling." Robert A. Hillman, Principles of Contract Law 300 (3d ed. 2014).

${ }^{50}$ According to Judge Richard Posner, good faith performance "is a stab at approximating the terms the parties would have negotiated had they foreseen the circumstances that have given rise to their dispute." Market St. Assocs., Ltd. P'ship v. Frey, 941 F.2d 588, 595 (7th Cir. 1991).

${ }^{51}$ Restatement (Second) of Contracts, 205, cmt. $a$.

52 Jacob \& Youngs, Inc. v. Kent, 129 N.E. 889, 891 (1921).

${ }^{53}$ See infra notes , and accompanying text.

${ }^{54}$ See, e.g., Steven Burton, Breach of Contract and the Common Law Duty to Perform in Good Faith, 94 Harv. L. Rev. 369 (1980).

${ }^{55}$ See supra note , and accompanying text.

${ }^{56}$ E.I. DuPont de Nemours \& Co. v. Pressman, 679 A.2d 436, 448 (Del. 1996).
} 
when is an employer in bad faith for terminating an employee notwithstanding the employer's right to terminate without cause ${ }^{57}$

Section 2.07(c) attempts to answer this question. Drawing on employment cases that have found bad faith, subsection (c) reveals two mandatory exceptions. Under (c)(1), an employer is in bad faith if it "terminates or seeks to terminate" an employee in order to prevent the employee from realizing rights or benefits that the employee would otherwise receive under the employment contract. An employer is also in bad faith under subsection (c)(2) if its motive for terminating an employee is to retaliate against the employee for lawful conduct under the employment contract or other law. The Restatement therefore ultimately finds limitations on the employer's right to terminate without cause--an employer is in bad faith if motivated by the desire to deprive the employee of its benefits or to retaliate.

Illustration 1 to Section 2.07 reveals the employment Restatement's approach in Section 2.07(c)(1). Based on Fortune v. National Cash Register Co., ${ }^{58}$ the illustration posits that an employer fires its sales employee, who had executed a sale of equipment, without cause. The result of the termination was that the employee lost 25 percent of a commission that would have been due according to the express contract if the employee had remained employed when the employer delivered the equipment and 30 days had elapsed without a customer complaint. The Illustration concludes that the employee "has an action against" the employer for the commission lost as a result of the termination. But the employee's rights run only to the commission. The employee cannot be reinstated or, I assume, recover any damages for lost salary.

In the actual Fortune case, the court affirmed a jury verdict that the employer's termination was in bad faith. Because Fortune only sought compensation for the lost commission, the case is not authority for Illustration 1's conclusion that the employee has no other rights after the termination. Other decisions support the Illustration's conclusion, however. ${ }^{59}$ This seems inconsistent with the finding of bad faith or at least too limiting of its effect. If the employer's conduct violated norms of "decency, fairness, and reasonableness," there seems little reason to insulate the employer from liability for some quantum of the employee's future salary as well, notwithstanding the at-will relationship. Put another way, good faith performance and at-will employment are not in conflict and "coexist" under these circumstances because the employee's "objectively reasonable expectations" are that the employer will not terminate the employee to deprive the employee of commissions and that the employer will be liable for expectancy damages if the employer does so. ${ }^{60}$

Illustration 1 to Section 2.07 and, for that matter, the Fortune case itself do not sufficiently underscore additional difficult hurdles employees face in establishing a bad-faith termination even under Section 2.07's framework. Perhaps most challenging, the employer may point to express contract language that seemingly permits termination. How can an employee

57 "[I]t is difficult to distinguish a 'bad faith' discharge from a no-cause discharge * * *." Metcalf .v Intermountain Gas Co., 778 P.2d 744, 749 (Idaho 1984).

58364 N.E.2d 1251 (Mass. 1977).

${ }^{59}$ See, e.g., Wagenseller v. Scottsdale memorial Hospital, 710 P.2d 1025 (Ariz. 1985).

${ }^{60}$ This conclusion satisfies the instruction set forth in E.I. DuPont de Nemours \& Co. v. Pressman, 679 A.2d 436, 448 (Del. 1996), quoted in text accompanying notes 
reasonably expect a commission, for example, if the contract expressly excludes one under the circumstances? Section 3.05 of the employment Restatement, dealing with the good-faith obligation in the context of compensation and benefits, appears to narrow employee rights in the face of just such express contract language. Comment $b$ to the section says "the express terms of the agreement between the parties control." Illustration 2 to Section 3.05, building on the Fortune case, posits that a term of the employment contract expressly states that if the employee is not on the payroll 30 days after the customer receives the equipment without complaint the additional 25 percent commission goes to the employee "servicing the account," not the terminated employee. Illustration 2 concludes that the terminated employee "has no claim" against the employer for the commission.

Comment $b$ to Section 3.05 and Illustration 2 seem too restrictive of employee rights. In fact, the court in Fortune expressly stated that "[a]ccording to a literal reading of the contract, NCR [the employer]" did not breach the contract, but it still found for the employee because of the employer's bad faith. ${ }^{61}$ Other courts facing just such circumstances also reason that courts should interpret express terms with the view that the parties likely intended a fair and just interpretation of them. For example, in Tymshare, Inc. v. Covell, ${ }^{62}$ an employer expressly enjoyed "sole discretion" to alter sales quotas of its employees. The employer raised the sales quotas, which deprived the employee of certain commissions. Then Judge Scalia nonetheless stated:

[A]greeing to such a provision would require a degree of folly on the part of these sales representatives we are not inclined to posit where another plausible interpretation of the language is available. It seems to us that the 'sole discretion' intended was discretion to determine the existence or nonexistence of the various factors that would reasonably justify alteration of the sales quota. Those factors would include . . . an unanticipated volume of business from a particular customer unconnected with the extra sales efforts of the employee assigned to that account; and ... a poor overall sales year for the company, leaving less gross income to be expended on commissions. ... But the language need not (and therefore can not reasonably) be read to confer discretion to [increase] the quota for any reason whatever--including . . . a simple desire to deprive an employee of the fairly agreed benefit of his labors. $^{63}$

Under the facts of Illustration 2, it would be unusual if either the employer or the sales employee reasonably expected that the term giving 25 percent of the commission to the servicing employee applied in situations where the employer's sole reason for terminating the sales employee was to deprive the sales employee of the commission. Further, such conduct, I would argue, contradicts the community's view of fairness and decency.

\footnotetext{
${ }^{61} 364$ N.E.2d at 101.

62727 F.2d 1145 (D.C. Cir. 1984).

63727 F.2d at 1155 . Some courts agree with this reasoning because it appeals to a sense of justice, and invokes the parties' likely intentions, thereby theoretically preserving contractual freedom. Other courts show concern that such an approach bends and stretches the notion of consent. See Robert A. Hillman, Good Faith Performance of Contracts in Late Twentieth-Century American Law, in Prescriptive Formality and Normative Rationality in Modern Legal Systems, 327, 331 (1994).
} 
Employees must also show that the employer's motivation was to deprive the employee of its just deserts. In a way, Fortune is an unfortunate precedent in this regard, at least from the perspective of those interested in employee rights. This is because the evidence appears almost a slam dunk for Fortune. As the court says, "We think that the evidence and the reasonable inferences to be drawn therefrom support a jury verdict that the termination of Fortune's twentyfive years of employment as a salesman with NCR the next business day after NCR obtained a $\$ 5,000,000$ order $* * *$ was motivated by a desire to pay Fortune as little of the bonus credit as it could." 64 Under the facts of Fortune, therefore, the court likely felt little contrition about interpreting the express terms of the contract to disapprove of such a termination. Employees likely will not have such striking evidence in the typical case.

The approach in Section 2.07 raises additional difficult questions. As already mentioned, the employment Restatement leaves open the possibility that Section 2.07(c) is not meant to preclude other instances of bad faith termination. ${ }^{65}$ Those exceptions, if any, await common law development, which will entail the difficult challenge of further harmonization of at-will employment and good faith. Obviously, if examples build up, the at-will principle necessarily will recede in importance and courts must remain aware of the importance of balancing at-will and other principles. ${ }^{66}$

In sum, the employment Restatement's move to place good-faith performance within the province of employment at will is a useful affirmation in the employment setting of the Restatement (Second) of Contracts' recognition of the obligation. Inevitably, as with the employment Restatement's nod to promissory estoppel, additional clarification awaits case law development.

\section{Other Exceptions to At-Will Employment In Brief}

I have chosen to focus on promissory estoppel and good faith performance as examples of the employment Restatement's approach to accommodating at-will employment termination and its counter-principles. Additional sections of Chapter 2 follow a similar approach. Concepts such as mutuality of obligation ${ }^{67}$ and material breach, ${ }^{68}$ for example, are helpfully situated within an employment contracts framework, but the drafters largely leave development of their content to future cases. ${ }^{69}$ This is not meant as a criticism. As with promissory estoppel and good faith performance, drafting in the shadow of contract law makes this strategy inevitable.

\section{The Restatement of Employment Law Chapter 2: An Evaluation}

A. What is the Purpose of the ALI Restatement of Employment Law?

\footnotetext{
${ }^{64} 364$ N.E.2d at 1258 (emphasis added). But NCR paid the commission to another employee so NCR did not gain from its actions. See Epstein, supra note , at .

${ }^{65}$ See supra notes , and accompanying text.

${ }^{66}$ Comment $b$ to section 2.07 states that "[t]his Section sets out two principal (though not necessarily exclusive) applications of the implied duty of good faith and fair dealing in the employment context."

${ }^{67}$ Section 2.04(f).

${ }^{68}$ Section 2.04(a)

${ }^{69}$ Chapter 2's treatment of "cause" is much more detailed and is very helpful. See Section 2.04.
} 
It is fair to say that the employment law Restatement and Chapter 2 were not received favorably by some critics during and after the drafting process. ${ }^{70}$ I will discuss some of the criticism shortly. Some of the fireworks can be attributed to the ambiguous role of ALI Restatements. At bottom is the question of whether Restatements literally are supposed to "restate" existing law or do they have a normative goal as well. To evaluate Chapter 2, some clarity about the project's purpose is necessary. This part therefore briefly discusses ALI's charge to the drafters of their Restatements.

The ALI lays out its overall goals on its website: "The American Law Institute is the leading independent organization in the United States producing scholarly work to clarify, modernize, and otherwise improve the law."71 According to the website, the work of the restatements was originally conceptualized as an effort to clarify the law: "The founding Committee had recommended that the first undertaking of the Institute should address uncertainty in the law through a Restatement of basic legal subjects that would tell judges and lawyers what the law was. The formulation of such a Restatement thus became ALI's first endeavor." ${ }^{72}$ Today, a Handbook for Reporters and others involved in projects describes Restatements as "aim[ing] at clear formulations of common law and its statutory elements or variations and reflect[ing] the law as it presently stands or might plausibly be stated by a court." ${ }^{73}$ The goal of restatements therefore is to clarify the law. According to ALI's website, the ALI intends another type of project, ALI's "Principles of the Law," to do the main normative work: "The Institute also engages in intensive examination and analysis of legal areas thought to need reform. This type of study generally culminates in extensive recommendations for change in the law and usually is published as Principles of the Law." ${ }^{74}$

Strictly speaking, then, the employment law Restatement's foremost goal should be to consider the ever-increasing, overly amorphous body of law and to boil it down into a clearer, coherent set of rules. ${ }^{75}$ But, of course, that is easier said than done. Reporters have to pick and

\footnotetext{
${ }^{70}$ See, e.g., Mathew W. Finkin et al., Working Group on Chapter 2 of the Proposed Restatement of Employment L: Employment Contracts: Termination, 13 Emp. Rts. \& Emp. Pol'y 93 (2009).

${ }^{71}$ ALI Overview, available at http://www.ali.org/index.cfm?fuseaction=about.overview (last accessed on 7/9/14).

${ }^{72}$ ALI Overview, available at http://www.ali.org/index.cfm?fuseaction=about.instituteprojects (last accessed on 7/9/14.

${ }^{73}$ The American Law Institute, Capturing the Voice of the American Law Institute; A Handbook for ALI Reporters and Those Who Review Their Work (2005), http://www.ali.org/doc/ALIStyleManual.pdf, last accessed on 7/11/14.

${ }^{74}$ Id. "Principles do not purport to restate but rather pull together the fundamentals underlying statutory, judicial, and administrative law in a particular legal field and point the way to a coherent (a principled, if you will) future." The American Law Institute, Capturing the Voice of the American Law Institute; A Handbook for ALI Reporters and Those Who Review Their Work (2005), http://www.ali.org/doc/ALIStyleManual.pdf, last accessed on 7/11/14. Maureen O'Rourke and I were the Reporters of the "Principles of the Law of Software Contracts." We chose to write "principles" instead of a Restatement in large part so that we could illuminate what we thought the law should be.

${ }^{75}$ Sources of information about rules include published and unpublished opinions, court orders, court dockets, legal briefs, and scholarship, adding to the challenge for restaters. Thanks to David Hoffman for this point.
} 
choose among conflicting rationales and holdings especially where there is no sense of a "majority rule" among courts or a consensus among experts on what is the better rule. ${ }^{76}$ They must employ standards such as good faith and reasonableness to capture the essence of some cases, which often only raises issues as to the meaning of such standards in various contexts. ${ }^{77}$ Reporters also must restate rules they fear may be over- or under-inclusive, which, of course, is not much of a clarification of the law at all. ${ }^{78}$ In addition, it is no secret that Restatements often delve into what the law should be despite the demarcation between Restatements and Principles projects. ${ }^{79}$ In fact, the Reporters Manual licenses such activity, albeit at a modest pace:

Restatements-“analytical, critical and constructive"-accordingly resemble codifications more than mere compilations of the pronouncements of judges. *** Although Restatements are expected to aspire toward the precision of statutory language, they are also intended to reflect the flexibility and capacity for development and growth of the common law. They are therefore phrased not in the mandatory terms of a statute but in the descriptive terms of a judge announcing the law to be applied in a given case. A Restatement thus assumes the perspective of a commonlaw court, attentive to and respectful of precedent, but not bound by precedent that is inappropriate or inconsistent with the law as a whole. $* * *$ A significant contribution of the Restatements has also been anticipation of the direction in which the law is tending and expression of that development in a manner consistent with previously established principles. Restatements are instruments for innovations of this sort. Nevertheless, the improvements wrought by Restatements are necessarily modest and incremental, seamless extensions of the law as it presently exists. An unelected body like The American Law Institute has limited competence and no special authority to make major innovations in matters of public policy. Its authority derives rather from its competence in drafting precise and internally consistent articulations of law. ${ }^{80}$

With the hurdles to clarification mentioned in Part I of this article, and keeping in mind the charge to ALI Reporters, I evaluate the employment Restatement in the next subsection. I focus on the latter part of the statement in the Reporters' Manual, which appears to harmonize ALI's somewhat conflicting descriptions of what Restatements are designed to do. In short, is Chapter 2 of the employment Restatement a "precise and internally consistent articulation[]" of employment termination and are the improvements suggested "modest and incremental, seamless extensions" of present law?

\footnotetext{
${ }^{76}$ Patterson, The Restatement of the Law of Contracts, 33 Colum. L. Rev. 397, 399 (1933) ("The meaning of Restatement becomes still more ambiguous when one looks at the diverse theories as to the interpretation of precedents.").

${ }^{77}$ James Gordley, European Codes and American Restatements: Some Difficulties, 81 Colum. L. Rev. 140, 147 (1981).

${ }^{78}$ Id. at 150 (citing Restatement (Second) of Contracts Section 90's admonition to apply it only "if injustice can $* * *$ be avoided by enforcement of the promise."

${ }^{79}$ The employment Restatement's foray into the law of good faith is an example.

${ }^{80}$ The American Law Institute, Capturing the Voice of the American Law Institute; A Handbook for ALI Reporters and Those Who Review Their Work (2005), http://www.ali.org/doc/ALIStyleManual.pdf, last accessed on 7/11/14.
} 


\section{B. Does Chapter 2 Satisfy the Goals of a Restatement?}

Chapter 2 of the employment Restatement satisfies the goals of a Restatement. The Chapter is largely a helpful and accurate framework of current law with incremental normative extensions. $^{81}$ For example, the Restatement situates at-will employment and the counterprinciples without a heavy hand in either direction. Moreover, it affirms the use of promissory estoppel notwithstanding remaining tension in the case law. Chapter 2 also suggests that promises can be enforceable without the specificity demanded of enforceable contracts. In addition, Chapter 2 not only recognizes the good-faith performance principle in the employment setting, but adopts it as mandatory term despite the jurisdictions that still debunk the theory. In addition, the Restatement helpfully identifies the two most prominent kinds of bad faith in the cases.

Another manner of evaluating Chapter 2 is by considering some of the criticisms of the Chapter. One complaint often heard was that the project lacked a unifying theory, ${ }^{82}$ but instead employed a "balkanized approach." ${ }^{83}$ Doubters also suggested that contract law was not a useful vehicle for analysis. ${ }^{84}$ Further, critics regretted the timing of the drafting of the Restatement, worrying that it would "freeze" unsettled or developing law. ${ }^{85}$ So, should the employment Restatement have presented a unified theory? Is contract law the appropriate conceptual framework, notwithstanding its pluralism? Should ALI have embarked on an employment Restatement at this time?

1. Should the employment Restatement have presented a unified theory? Some analysts criticized the employment Restatement for lacking an underlying, unifying theory, as if such a thing would magically explain employment (and termination) law and protect employees under the appropriate circumstances. Indeed, Chapter 2, although denominated Employment Contracts: Termination, does lack such a theory but, as with general contract law, there is no underlying theory that would capture the richness of the law of termination of employment contracts. ${ }^{86}$ For

\footnotetext{
${ }^{81}$ It is more than a "repackaging" of common law. But see Rachel Arnow-Richman, Response to Working Group on Chapter 2 of the Proposed Restatement of Employment Law: Putting the Restatement in its Place, 13 Employee Rts. \& Emp. Pol'y J. 143, 143 (2009) (hereinafter Arnow-Richman, Response).

82 "In assessing parties' rights and obligations, some courts, in some contexts, veer toward contract formalism, emphasizing issues of assent, consideration, and narrowly defined contract defenses. Other courts in the same contexts (or the same courts in different contexts) place greater emphasis on bargaining disparities, relational norms, and policy considerations, often bending contract rules to achieve larger goals. Thus, a Restatement of employment law could comprise a meaningful contribution to the field if it were to expose or suggest a governing theory of employment contracts." Rachel Arnow-Richman, Contract "Lite"; The ALI's Draft Restatement of Employment Law Chapter 2 (Termination), available at http://lawprofessors.typepad.com/laborprof_blog/2009/05/arnowrichmans-critique-chapter-2-of-theproposed-restatement.html (last accessed 9/19/14).

83 Id.

${ }^{84}$ Id. "Absent a clear theory of the relationship between contract and employment, the Restatement cannot serve as a comprehensive or even useful account of how the law treats recurring factual problems." Id.

${ }^{85}$ See, e.g., Mathew W. Finkin et al., Working Group on Chapter 2 of the Proposed Restatement of Employment L: Employment Contracts: Termination, 13 Emp. Rts. \& Emp. Pol'y 93, 94-95 (2009).

${ }^{86}$ Robert A. Hillman, Richness of Contract Law (1997).
} 
example, promissory estoppel is an independent theory of obligation and in truth is closer to tort law than contract. Good faith performance depends on fairness and justice and thus introduces elements that are independent of assent and agreement. Because general contract law has no overarching theory of its own it is no surprise that a treatment of employment law would not either. By identifying the issues and situating the diverse legal principles that arise in the termination context, the employment Restatement will be helpful to courts. This is all that an attempt to corral the law of employment termination can hope for.

2. Is contract law the appropriate conceptual framework for employment agreements? Notwithstanding contract law's heterogeneity, dissenters worried that it is unfit to regulate employment arrangements: "Can a relationship really be deemed a contract at all if it's unbreachable?" ${ }^{87}$ Technically, under contract law's mutuality-of-obligation requirement, the critics have a point. Employment-at-will arrangements are illusory if the parties have no obligation to each other. But employers may have an obligation to give notice of termination. ${ }^{88}$ In addition, if an employee has supplied consideration to support an employer's promise of justcause employment or employment of a certain duration, such as by leaving another job at the request of the employer, contract law enforces the employer's promise. ${ }^{89}$ These examples meet all of the requisites of an enforceable contract. ${ }^{90}$

More important, to deny employment termination the contract imprimatur would only impoverish the analysis. In its broadest conception, a contract is "a promise or set of promises for the breach of which the law gives a remedy or the performance of which the law recognizes as a duty." ${ }^{91}$ Of course, such a definition does not tell us very much because it only leads to the question of when is a promise enforceable. ${ }^{92}$ But by calling employment termination a contract problem in Chapter 2, the employment Restatement thereby invokes the whole body of precedent establishing what promises are enforceable and why. Such an inquiry encompasses agreements supported by consideration, detrimental reliance on a promise, quasi contracts and more and, as shown, applies to the mutuality problem discussed above. If contract were replaced as an analytical tool, the existing framework for examining theories such as promissory estoppel and good faith performance would also be lost at little or no gain.

3. Should ALI have embarked on an employment Restatement at this time? The law and the society it governs do not stand still, and I doubt that there is ever an optimal time to restate the law. This is especially true of employment termination law because of the dynamic nature of labor markets and because of the effect of new technologies on the nature of business activities.

\footnotetext{
${ }^{87}$ Mathew W. Finkin et al., Working Group on Chapter 2 of the Proposed Restatement of Employment L: Employment Contracts: Termination, 13 Emp. Rts. \& Emp. Pol'y 93, 110 (2009).

${ }^{88}$ See Restatement of the Law Third, Employment Law, Section 2.03, Reporters' Notes to Comment $f$.

${ }^{89}$ But many courts are reluctant to accept this approach. See, e.g., Stewart Macaulay, Jean Braucher, and John Kidwell, Contracts: Law in Action 440 (3d ed. 2010).

${ }^{90}$ See, e.g., Larry Blades, Employment A Will VS Individual Freedom: On Limiting the Abusive Exercise of Employer Power, 67Colum. L. Rev. 1404, 1419 (1967).

${ }^{91}$ Baehr v. Penn-O-Tex Oil Corp., 104 N.W.2d 661, 664 (Minn. 1960).

92 Id.
} 
Still, a plausible argument can be made that the common law has not moved very much on employment at will and its counter-principles in the last 20 years or so. ${ }^{93}$ Whatever the trend, the employment Restatement performs a useful service now by identifying issues and presenting a framework for future development. In addition, because employment termination relies on broad principles such as reasonableness and good faith, it can hardly "freeze" the law. Perhaps a helpful analogy to the Restatement's role is the use by lawyers of preliminary agreements that memorialize terms in negotiation and form the outline for future agreements. ${ }^{94}$ The employment Restatement and preliminary agreements share a common goal of seeking to organize and simplify an ongoing project once an abundant amount of data has been amassed.

Further, future development of the common law of employment termination is hard to predict. Are courts going to whittle away at at-will employment or, on the other hand, narrow counter-principles? So those in favor of greater employee or employer rights cannot confidently prefer the common law to what the employment Restatement has to offer. ${ }^{95}$

III. What if the project had been "Principles of Employment Law?"

In this part, I ponder the following question: Suppose the ALI project on employment termination in Chapter 2 had been part of a "Principles" project instead of a restatement. What might "Employment Termination Principles" look like? I should disclose that my own work for the ALI as reporter of Principles of the Law of Software Contracts freed me from the restraints of a restatement and allowed me to ponder more directly what the law should be. As I wrote in the introduction to the Principles, "[i]nstead of restating the law, a "Principles" project accounts for the case law and recommends best practices, without unduly hindering the law's adaptability to future developments." 96 Because the nature of a restatement is different from a principles project, however, I do not mean to suggest that the drafters of the employment Restatement necessarily should have adopted any of the following suggestions. Nor do I want to suggest that the following "Principles" are anything more than my own view of the path that employment termination should take. (I must admit it is a luxury to make suggestion without having to balance the rather adamant views of opposing interests.) But I would argue that the following suggestions, although mainly bolstering employee protections, also preserve the important role of employment at will. My focus is again on Chapter 2's use of promissory estoppel and good faith performance as counter-principles to the default rule of at-will employment.

As part of a "Principles" project, the Reporters could have elaborated on how promissory estoppel should operate in the context of at-will employment. As I described in Part I, crucial are whether the employer made a promise and whether the employee should have reasonably relied on the promise. ${ }^{97}$ For purposes of evaluating whether a communication constituted a

${ }^{93}$ Email message from Stewart Schwab to Robert Hillman, 9/27/14.

${ }^{94}$ See, e.g., Restatement (Second) of Contracts 27 (Existence of Contract Where Written Memorial is Contemplated).

${ }^{95}$ Arnow-Richman, Response, supra note , at 145.

${ }^{96}$ Principles of the Law of Software Contracts 2 (ALI 2009). Other Principles projects include Principles of Corporate Governance: Analysis and Recommendations and Principles of the Law of Family Dissolution: Analysis and Recommendations.

${ }^{97}$ See supra notes, and accompanying text. 
promise, contract law's rules of interpretation should apply. First, courts should examine the words of the communication to see whether under their dictionary meaning they constitute an assurance as to future job security. Looking at the plain meaning of language such as "your job is secure," 98 "there is no need $* * *$ to look elsewhere," with [us] until age sixty-five," 100 and [you will] remain employed by the company,"101 it is difficult to see how these communications can be anything other than "an assurance" of a secure future with the employer. The absence of more detail, such as a specific duration, should not matter when examining the dictionary meaning. As already noted, Comment $c$ of the employment Restatement appears to make this point: "Where the conditions for promissory estoppel are present, promises may be enforceable even though an agreement itself would not be enforceable for lack of a written document." The language of the Comment would have been more clear and capture more cases, however, if it read that a promise may be enforceable although not definite enough to be an enforceable contract. ${ }^{102}$ For that matter, Section 2.02(b) in a Principles project could have invoked a broader conception of estoppel, for example, to include conduct that induces reasonable reliance. ${ }^{103}$

Next, a Principles project could focus on the circumstances in which the employer made the assurance, including the presence of an express or default rule of at-will employment. As with general contract law's use of trade custom, course of dealing, and course of performance to fill out the reasonable meaning of agreements, employment termination principles could look to these sources of meaning to supplement the plain meaning of a communication and to determine whether the employee's reliance was reasonable. As for the latter, if an employer tells an employee that "your job is secure" and employees regularly rely on such a statement in the particular trade that should be strong evidence that the employee's reliance was reasonable. ${ }^{104}$ Similarly, if the employer has made such statements in the context of previous employment relationships and the employee relied on them, this course of dealing suggests the employee is reasonable to rely once again. ${ }^{105}$ Finally, if the issue involves a cluster of positive communications from the employer, this course of performance would be relevant in determining the reasonableness of reliance. ${ }^{106}$

In assessing the reasonableness of an employee's reliance, a Principles project could also devote more attention to the often uneven relationship between employer and employee. To review, many employees have invested their time, money, and psyche in their job. Further, they may have few or no alternatives and believe the employer will look out for their welfare. These employees lack the wherewithal to withstand employer inducements designed to create a loyal

\footnotetext{
${ }^{98}$ Corradi v. Soclof, 1995 WL 322311 (Ct. App. Ohio), discussed in Hillman, Unfulfilled Promise at 13.

${ }^{99} \mathrm{Id}$

${ }^{100}$ Dickens v. Equifax Services, Inc., 1996 WL 192973 (10th Cir. 1996), discussed in Hillman,

Unfulfilled Promise, supra note , at 14.

${ }^{101}$ Id.

${ }^{102}$ See Hoffman v. Red Owl Stores, 133 N.W. 2d 267 (Wis. 1965).

103 Section 2.02(d) helps fill the void.

${ }^{104}$ U.C.C. section 1-303(c).

105 U.C.C. section 1-303(b).

${ }^{106}$ U.C.C. section 1-303(b).
} 
work force. ${ }^{107}$ Contract law evaluates the reasonableness of a party's actions by taking into account the attributes and circumstances of the relying actor. ${ }^{108}$ To determine whether an employee reasonably relied on the employer's inducements, therefore, a court should ask what a reasonable party in the shoes of the employee would have done.

A Principles project on employment termination could also reject cases that dismiss an employee's reasonable reliance when it consists of failing to enter the job market. If the evidence reveals that the employee could have secured other work but was induced not to test the market and the evidence proves with sufficient certainty what the employee's new salary would have been there is little reason to bar such evidence or reject that theory of recovery. In fact, under the avoidable consequences rule, courts use such evidence against employees to diminish their damages for wrongful termination if the employee does not accept reasonable alternative employment. ${ }^{109}$

As for the good-faith obligation, a Principles project on employment termination could follow the lead of then Judge Scalia in the Tymshare case and clarify that courts should not allow express language to trump the good-faith obligation. ${ }^{110}$ Instead, courts should interpret express terms in light of the likelihood that the parties intended performance to be fair and reasonable.

A Principles project also could be more attentive to how courts determine the motives of an employer who fires an employee. The test should be objective as in general contract law: based on the circumstances, what would a reasonable person believe was the employer's motive? And the project could enumerate additional examples of possible bad faith motives. Such motives may include personal animosity toward a highly functioning employee or retaliation for the employee's reasonable conduct outside of employment. ${ }^{111}$ Firing an employee for such reasons belies the employee's reasonable expectations or the community's view of fairness even in an at-will employment arrangement. In addition, an employer who justifies termination by fictionalizing the grounds for dissatisfaction with the employee's performance is in bad faith because an employee or the community would not reasonably expect such conduct even in an atwill contract. $^{112}$

For the reasons already discussed, a Principles project could establish that an employer who terminates an employee in bad faith to deprive the employee of commissions should be liable for the employee's commissions, but also expectancy damages notwithstanding the at-will relationship. ${ }^{113}$ This result, although likely contrary to the prevailing view, ${ }^{114}$ improves the law by creating an additional employer incentive not to terminate in bad faith.

\footnotetext{
${ }^{107}$ See supra notes , and accompanying text.

${ }^{108}$ Hillman, Principles of Contract Law 48-49 (2014).

${ }^{109}$ Id. at 174.

110 See supra notes, and accompanying text.

${ }^{111}$ Reporters' Notes to Comment $b$ cites cases that support such additional bad faith examples. See also Mathew W. Finkin et al., Working Group on Chapter 2 of the Proposed Restatement of Employment L: Employment Contracts: Termination, 13 Emp. Rts. \& Emp. Pol'y 93, 138 (2009). But see E.I. DuPont de Nemours \& Co. v. Pressman, 679 A.2d 436 (Del. 1996).

${ }^{112}$ E.I. DuPont de Nemours \& Co. v. Pressman, 679 A.2d 436 (Del. 1996).

${ }^{113}$ See supra notes , and accompanying text.
} 
Finally, ambitious drafters of a Principles project could account for today's reality of employees increasingly at risk of termination and facing frequent job searches. According to one analyst, "[w]hat we need going forward is a contract theory of worker protection that focuses on enabling continued labor market participation rather than preserving particular jobs."115 One approach to this problem in a Principles project would be to declare that good-faith performance requires meaningful notice before termination and severance pay if notice is not feasible because of unforeseen conditions. ${ }^{116}$ Perhaps this is not too much of a stretch under the reasonable expectations or community standards approaches of good-faith performance. But such an approach obviously raises significant issues, including whether such protection makes economic sense and, if so, how to implement the strategy. As to the former issue, the benefits of protecting employees may be greatly outweighed by the costs to employers of creating an obligation in the context of negative business circumstances. As to the latter, questions arise such as when must notice be given and how should severance pay be calculated? Relatedly, would employers pass on the costs of such a program to employees in the form of reduced wages? ${ }^{117}$ Perhaps any such strategy in favor of employees terminated in poor economic times would best be handled in a statute that lawmakers could model after existing efforts. ${ }^{118}$

\section{Conclusion}

Contract law is useful and succeeds in guiding exchange transaction largely because it is multidimensional and practical. ${ }^{119}$ It lacks a dominant vision, but instead embraces disorder and contradiction. This is a good thing because no single theory could encompass the entire set of social and economic forces that are implicated in exchange agreements. ${ }^{120}$

Chapter 2 of the employment Restatement on termination embodies a subset of contract law issues, so it should be no surprise that the Chapter reflects contract law's heterogeneity. So the problem of sorting out lawful terminations of employees from wrongful ones cannot be resolved, it can only be tempered by establishing a framework for analysis. Based on an analysis of Chapter 2's treatment of at-will, promissory estoppel, and the obligation of good faith, and based on the role of an ALI restatement, the employment Restatement largely meets this challenge.

\footnotetext{
114 See, e.g., Wagenseller v. Scottsdale memorial Hospital, 710 P.2d 1025 (Ariz. 1985).

${ }^{115}$ Arnow-Richman, Response, supra note , at 152.

116 See Rachel Arnow-Richman, Just Notice: Re-Reforming Employment At Will, 58 UCLA L. Rev. 7 (2014). Notice is not required in many at-will jurisdictions. See Mathew W. Finkin et al., Working Group on Chapter 2 of the Proposed Restatement of Employment L: Employment Contracts: Termination, 13 Emp. Rts. \& Emp. Pol'y 93, 108 (2009).

${ }^{117}$ For possible responses to these questions, see Arnow-Richman, Just Notice, supra note .

118 See, e.g., 29 U.S.C. 2102, Notice required before plant closings and mass layoffs.

${ }^{119}$ Robert A. Hillman, Richness of Contract Law 268-269 (1997).

${ }^{120}$ Id.
} 